\title{
Fungi Causing Storage Rot of Apple Fruit in Integrated Pest Management System and their Sensitivity to Fungicides
}

\author{
Lelde Grantina-Ievina \\ Latvian Plant Protection Research Centre, Struktoru street 14A, Rīga, LV - 1039, Latvia
}

\begin{abstract}
Apple fruit rot can be caused by several fungi. In Northern Europe, the most common storage rot, Bull's eye rot, is caused by Neofabraea spp., bitter rot by Colletotrichum spp., brown rot by Monilinia fructigena, grey mould is caused by Botrytis cinerea and Fusarium rot by several Fusarium species. Blue mold decay caused by Penicillium expansum is an important disease in several European countries. Incidence of different causal agents may vary depending on cultivar, climate during growing season and agricultural practices. The main objective of the study was to obtain baseline information about apple rot-causing fungi, their incidence during fruit storage and to evaluate the fungicide sensitivity of most of isolated fungal species. The study was performed during the storage period of apples after the growth season of 2013. Rotten apples were sorted in the storage and part of them was brought to the laboratory in order to obtain fungal isolates. Fungi were identified according to the morphological characteristics and sequencing of the ITS1-5.8S-ITS2 region. During storage in February and March the total percentage of rotten apples in various cultivars varied from 3.6 to $58.9 \%$. All post-harvest diseases described in Northern Europe were detected. In part of the storehouses apple rot caused by Cadophora luteo-olivacea was observed. Alternaria spp. and Cladosporium spp. were detected on few apples as secondary infection agents. Using the most often isolated fungal species, sensitivity tests were performed against five commonly used fungicides. In general, the sensitivity of tested fungi to the fungicides was high with exception of several Neofabraea and Alternaria isolates.
\end{abstract}

Key words: Colletotrichum spp., Monilinia fructigena, Neofabraea alba, Neofabraea malicorticis, Penicillium spp.

\section{Introduction}

Apple rot is an economically significant disease on apple (Malus ' domestica Borkh) and can be caused by several filamentous fungi with worldwide distribution like Penicillium expansum Link. and Botrytis cinerea Pers. that are common and causing significant economic losses in the USA and Europe (Sutton et al., 2014). It has been shown that in Northern Europe, particularly in Norway, the most important storage diseases in organically grown apples were caused by Colletotrichum acutatum J. H. Simmonds (bitter rot) and Neofabraea spp. (Bull's eye rot) up to 64 and $30 \%$ respectively from all rotten apples (Borve, Roen, \& Stensvand, 2013). Grey mould caused by Botrytis cinerea, Fusarium rot caused by several Fusarium species, brown rot caused by Monilinia fructigena (Aderh \& Ruhland) Honey and blue mold decay caused by $P$. expansum were found more rarely (Borve, Roen, \& Stensvand, 2013). Apple rot studies in Denmark and Germany about organic orchards or orchards not treated with fungicides after petal fall have shown that Neofabraea alba (E.J. Guthrie) Verkley and Neofabraea perennans Kienholz were the most common storage-rot fungi (up to $62 \%$ ). Other fungi, such as Neonectria galligena (Bres.) Rossman \& Samuels, M. fructigena, Cladosporium spp., $P$. expansum, Phacidiopycnis washingtonensis Xiao \& J.D.Rogers, C. acutatum, Gibberella avenacea R.J. Cook, B. cinerea were present up to 5\% (Maxin et al., 2012a). The Fusarium rot has been detected on 9 to $30 \%$ of apples depending on cultivar stored in Ultra Low Oxygen (ULO) conditions in Croatia (Sever et al., 2012). Blue mold decay caused by $P$. expansum is damaging 30 to $60 \%$ of cold-stored apples in France, and it is important disease not only in other European countries but also in the USA (Morales et al., 2010). It is reported that Alternaria alternata causes core rot (Niem et al., 2007) and rot around injuries or at calyx (Sutton et al., 2014). The rubbery rot caused by P. washingtonensis is considered as a new emerging disease in Northern Europe, and it is reported to cause rot in up to $10 \%$ of apples stored in ULO conditions (Weber, 2011).

Apple rot incidence may vary depending on cultivar (Sever et al., 2012); Weber, 2011) and harvest time (Borve, Roen, \& Stensvand, 2013). Climate conditions during growing season can also have a significant impact, for example, on spore dispersal and following brown rot incidence as it is proved in the conidial dispersal rates in the case of $M$. fructigena in organic and integrated apple orchards in Hungary (Holb, 2008).

\footnotetext{
* Corresponding Author's email: lelde.grantina-ievina@laapc.lv
} 
Apples from integrated orchards have a lower disease incidence in comparison to organic orchards in the case of brown rot (Holb, 2008). Similarly, apples from conventional orchards have been reported to have lower levels of storage rots (blue mold, brown mold and Bull's eye rot) in comparison with organic orchards (DeEll \& Prange, 1993).

Two mechanisms of infection can be determined, primary and secondary infection. The primary infection usually happens in orchards or during sorting before storage. The secondary infection happens when fungal mycelium and spores spread from infected apples to uninfected apples (Dutot, Nelson, \& Tyson, 2013).

The sensitivity of above mentioned apple rotcausing fungi to the fungicides is various. It is reported that $N$. alba shows low sensitivity to fungicides. For instance, in the investigation in the USA it was shown that in in vivo conditions from three tested fungicides (copper sulfate, trifloxystrobin, ziram) only the copper sulfate reduced the conidial production by $N$. alba but none of the fungicides used reduced the germination of conidia (Henriquez, Sugar, \& Spotts, 2006). Boscalid with pyraclostrobin had shown high efficacy in preharvest application against P. expansum and B. cinerea (Xiao \& Boal, 2009). High resistance of several $P$. expansum isolates has been recorded against benomyl, thiabendazole and diphenylamine (Sholberg et al., 2005). Azoxystrobin, difenoconazole, Polyoxin B and trifloxystrobin have been effective against $A$. alternata causing core rots (Reuveni \& Sheglov, 2002).

In the present investigation apples from integrated orchards were examined at the end of the storage period in February and March. The aim of the study was to determine the main causal agents of apple rot during storage and to evaluate the sensitivity of most isolated fungal species to commonly used fungicides.

\section{Materials and Methods \\ Inspected Apple Storehouses}

Apples grown in seven orchards (Table 1) were stored in four storehouses: (1) a farm in Beverina region (northern part of the country) with average

Table 1

\section{Applications of fungicides and other preparations in apple orchards involved in the investigation}

\begin{tabular}{|c|c|c|}
\hline $\begin{array}{l}\text { Orchard and } \\
\text { location }\end{array}$ & $\begin{array}{l}\text { Treatments with fungicides and calcium preparations, } \\
\text { dose }\left(\mathrm{kg} \text { or L ha } \mathrm{h}^{-1}\right) \text { and application time in } 2013\end{array}$ & $\begin{array}{l}\text { Total treatments } \\
\text { with fungicides }\end{array}$ \\
\hline $\begin{array}{l}\text { I Beverina } \\
\text { region }\end{array}$ & $\begin{array}{l}\text { Funguran OH 1.5 L (06.-07.05.), Score } 250 \mathrm{EC} 0.2 \mathrm{~L}(22.05 .) \text {, Dithane NT } \\
2 \mathrm{~kg}(28.05 .) \text {, Chorus } 50 \mathrm{WG} 0.46 \mathrm{~kg}(08 .-10.06 .) \text {, Score } 250 \mathrm{EC} 0.185 \mathrm{~L} \\
(20 .-21.07 .) \text {, Chorus } 50 \mathrm{WG} 0.45 \mathrm{~kg}(12.08 .) \text {, five treatments with } \mathrm{CaCl}_{2} \text {, } \\
\text { in total } 19 \mathrm{~kg}(18.07 .-28.08 .)\end{array}$ & 6 \\
\hline $\begin{array}{l}\text { II Bauska } \\
\text { region }\end{array}$ & $\begin{array}{l}\text { Funguran OH } 1.5 \mathrm{~L}(03.05 .) \text {, Dithane NT } 3 \mathrm{~kg}(08.05) \text {, Effector } 0.3 \mathrm{~kg} / \\
\text { Chorus } 50 \mathrm{WG} 0.25 \mathrm{~kg}(20.05 \text {.), Effector } 0.3 \mathrm{~kg} / \text { Score } 250 \text { EC } 0.25 \mathrm{~kg} \\
\text { (26.05.), Effector } 0.3 \mathrm{~kg} / \text { Score } 250 \text { EC } 0.2 \mathrm{~L}(02.06 .)\end{array}$ & 5 \\
\hline $\begin{array}{l}\text { III Pure } \\
\text { region A }\end{array}$ & $\begin{array}{l}\text { Champion } 4 \mathrm{~kg} \text { (03.05.), Effector } 0.25 \mathrm{~kg} / \text { Score } 250 \text { EC } 0.15 \mathrm{~L}(14.05 .) \text {, } \\
\text { Chorus } 50 \mathrm{WG} 0.4 \mathrm{~kg}(20.05 .) \text {, Score } 250 \text { EC } 0.15 \mathrm{~L} / \text { Dithane NT } 2 \mathrm{~kg} \\
\text { (29.05.), Chorus } 50 \mathrm{WG} 0.4 \mathrm{~kg}(06.06 .) \text {, Dithane NT } 2 \mathrm{~kg}(28.06 .) \text {, Score } \\
250 \mathrm{EC} 0.15 \mathrm{~L} / \text { Dithane NT } 2 \mathrm{~kg}(17.07 .)\end{array}$ & 7 \\
\hline $\begin{array}{l}\text { IV Pure } \\
\text { region B }\end{array}$ & $\begin{array}{l}\text { Funguran OH } 1.5 \mathrm{~L} \text { (04.05.), Difo } 250 \text { EC } 0.2 \mathrm{~L} / \text { Dithane NT } 2 \mathrm{~kg} \\
\text { (11.05.), Chorus } 50 \mathrm{WG} 0.4 \mathrm{~kg}(19.05 .), \text { Difo } 0.2 \mathrm{~L} / \text { Dithane } 2 \mathrm{~kg} \\
\text { (27.05.), Dithane NT } 2 \mathrm{~kg}(04.06 .)\end{array}$ & 5 \\
\hline $\begin{array}{l}\mathrm{V} \text { Talsu } \\
\text { region }\end{array}$ & $\begin{array}{l}\text { Funguran OH } 1.25 \mathrm{~L}(05.05 .) \text {, Chorus } 50 \text { WG } 0.2 \mathrm{~kg} \text { (13.05.), Chorus } 50 \\
\text { WG } 0.2 \mathrm{~kg} / \text { Effector } 0.25 \mathrm{~kg} \mathrm{~h}^{-1}(30.05 .) \text {, Score } 250 \mathrm{EC} 0.15 \mathrm{~L} / \text { Effector } \\
0.25 \mathrm{~kg}(18.06 .) \text {, Chorus } 50 \mathrm{WG} 0.2 \mathrm{~kg} / \text { Effector } 0.25 \mathrm{~kg}(15.08 .)\end{array}$ & 5 \\
\hline $\begin{array}{l}\text { VI Vandzene } \\
\text { region }\end{array}$ & $\begin{array}{l}\text { Champion } 4 \mathrm{~kg}(03.05 .) \text {, Dithane NT } 2 \mathrm{~kg} / \text { Score } 250 \text { EC } 0.2 \mathrm{~L}(20.05 .) \text {, } \\
\text { Dithane NT } 2 \mathrm{~kg} / \text { Score } 250 \text { EC } 0.2 \mathrm{~kg}(28.05 .) \text {, Difo } 250 \text { EC } 0.2 \mathrm{~L} \\
\text { (14.06.) or Dithane NT } 2 \mathrm{~kg} / \text { Score } 0.2 \mathrm{~L}(14.06 .)\end{array}$ & 4 \\
\hline $\begin{array}{l}\text { VII Jelgava } \\
\text { region }\end{array}$ & $\begin{array}{l}\text { Champion } 1 \%(01.05 .) \text {, Effector } 0.3 \mathrm{~kg}(11.05 .) \text {, Chorus } 50 \mathrm{WG} 0.33 \\
\mathrm{~kg}(30.05 .), \text { Dithane NT } 2 \mathrm{~kg}(15.06 .) \text {, Chorus } 50 \mathrm{WG} 0.33 \mathrm{~kg}(27.06 .) \text {, } \\
\text { Effector } 0.3 \mathrm{~kg} / \mathrm{CaCl}_{2} 1 \%(07.07 .) \text {, Chorus } 50 \mathrm{WG} 0.33 \mathrm{~kg} / \mathrm{CaCl}_{2} 1 \% \\
\text { (28.07.) }\end{array}$ & 7 \\
\hline
\end{tabular}


air temperature in the storage $1-3{ }^{\circ} \mathrm{C}$ and average relative air humidity $80-90 \%$ (orchard I), (2) a farm in Bauska region in the central part of Latvia (2$3{ }^{\circ} \mathrm{C}, 90 \%$; orchard II); (3) a joint storage for several farmers in Pure region in Western part of Latvia (4-4.5 $\left.{ }^{\circ} \mathrm{C}, 80-90 \%\right)$; (4) a farm in Vandzene region in Western part of Latvia $\left(4{ }^{\circ} \mathrm{C}, 85-90 \%\right.$; orchard VI). In the joint storage in Pure region, the inspected apple cultivars had been grown in various orchards: 'Sinap Orlovskij' in the orchard III, 'Belorusskoje Malinovoje' on the farm in Pure region (orchard IV) and 'Antej' on the farm in Talsi region (orchard V). From apples originating from the orchard VII few fungal isolates were obtained for comparison in the fungicide sensitivity tests, the storage site itself was not inspected.

The apple storehouses were inspected in February and March, 2014. In the storage, healthy and rotten apples in the containers were counted, one container for each cultivar containing from 600 to 27000 apples. Diseases were identified according to their symptoms on the location or later in the laboratory. The following apple cultivars were monitored: 'Ligol', 'Tellissaare', 'Antej', 'Sinap Orlovskij', 'Belorusskoje Malinovoje', 'Auksis', 'Lobo' and 'Forele'.

The applications of fungicides and calcium preparations in the mentioned apple orchards in 2013 are listed in Table 1. It has to be admitted that farmers in Latvia only occasionally use fungicides targeted specially against apple fruit rot. Only treatments against apple scab are usually carried out.

\section{Isolation and Identification of Fungi}

The fungal material (mycelium and spores) from rotten apples was directly subjected to light microscopy or after a few days long incubation of rotten apples in the incubator $\left(20 \pm 2{ }^{\circ} \mathrm{C}\right)$. From the rotten apples pure cultures of fungi were isolated on the potato dextrose agar (PDA) (Biolife, Italy). Fungal cultures were identified using morphological characteristics (Crous et al., 2019; Sutton et al., 2014); Watanabe, 2002) or with molecular biology methods sequencing part of the ITS1-5.8S-ITS2 region. Genomic DNA from approximately $0.25 \mathrm{~g}$ of mycelia was extracted using the E.Z.N.A. Fungal DNA Mini kit (Omega Bio-Tek, USA). The following primers were used: ITS4, universal for eukaryotes (White et al., 1990); ITS1F, specific for fungi (Gardes \& Bruns, 1993). The PCR reactions in SensoQuest Labcycler 48 (SensoQuest, Germany) were carried out in $25 \mu \mathrm{l}$ volume. The mixture contained $12.5 \mu \mathrm{l}$ Hot Start Master Mix 2X, $0.375 \mu$ Bovine Serum Albumin $20 \mathrm{mg} \mathrm{ml}^{-1}$ (all reagents from Thermo Scientific Fermentas Molecular Biology Solutions,
Lithuania), $0.5 \mu \mathrm{l}$ of each $10 \mu \mathrm{M}$ primer (Integrated DNA Technologies, USA), $10.125 \mu$ sterile distilled water and $1 \mu \mathrm{l}$ of DNA template. The PCR conditions were as follows: the initial denaturation step of 4 min at $95{ }^{\circ} \mathrm{C}, 40 \mathrm{~s}$ of denaturation at $95^{\circ} \mathrm{C}, 40 \mathrm{~s}$ of annealing at $52^{\circ} \mathrm{C}, 1 \mathrm{~min}$ of primer extension at $72^{\circ} \mathrm{C}$ (30 cycles) and final extension $10 \mathrm{~min}$ at $72^{\circ} \mathrm{C}$.

Amplified DNA fragments were treated with FastAPтM Thermosensitive Alkaline Phosphatase and Exonuclease I (Thermo Scientific Fermentas Molecular Biology Solutions, Lithuania) and sequenced by Macrogen Europe (Amsterdam, the Netherlands). Double stranded sequences of PCR amplicons were assembled using Staden Package 1.6.0. (Bonfield, Smith, \& Staden, 1995). The resulting consensus sequences were used in BLASTN homology search against the National Centre for Biotechnology Information nucleotide database (http://www.ncbi.nlm.nih.gov).

Identification of such fungi as Cadophora luteoolivacea (J.F.H. Beyma) T.C. Harr. \& McNew and Alternaria alternata (Fr.) Keissl. apple pathotype (A. mali Roberts) was further proved by specific PCR using the following primers: Clm-REV and Clu-FOR or Cma-FOR specific to ITS1-5.8S-ITS2 region of $C$. luteo-olivacea or C. malorum, respectively (Spadaro et al., 2011) and LinF1 and LinR specific to $A M T$ gene of $A$. alternata apple pathotype (A. mali) (Johnson et al., 2000).

Sequences of the ITS1-5.8S-ITS2 region of 59 fungal isolates were submitted to the GenBank (accession numbers KP903568-KP903626, KT923785-KT923789). All isolates were preserved in $-86{ }^{\circ} \mathrm{C}$ freezer in the collection of Latvian Plant Protection Centre.

\section{Application of Koch's Postulates}

With most often isolated fungal species from this and previous investigation of Latvian Plant Protection Centre (Volkova \& Juhnevica-Radenkova, 2015) the Koch's postulates were applied using the basic principles of the methodology described in other investigations (Mari et.al., 2012; Xiao \& Rogers, 2004). Inoculation was performed on apples sterilized for $2 \mathrm{~min}$ in $2 \%$ hypochlorite solution and rinsed with deionized water. In apples, the inoculation, a manual cut with a sterile scalpel up to $3 \mathrm{~mm}$ deep, with a small piece of fungal mycelia and/or spores from the cultures grown 14 days on PDA was done. After inoculation the apples were placed in sterile plastic boxes on the wet paper towel and incubated at $20 \pm 2{ }^{\circ} \mathrm{C}$ up to 39 days. After incubation reisolation of the pathogenic fungi was performed and these were identified according to the morphological characteristics. 
Fungicide Sensitivity Tests

With most often isolated fungal species (N. alba, 11 isolates; N. malicorticis, five isolates; C. luteo- olivacea, three isolates; A. alternata, six isolates) representing various orchards fungicide sensitivity tests were carried out against five fungicides (Table 2)

Table 2

Fungicides and their concentrations used in the fungicide sensitivity tests

\begin{tabular}{|c|c|c|c|c|c|c|c|}
\hline \multirow{2}{*}{$\begin{array}{l}\text { Fungicide, active substance, } \\
\text { concentration }\end{array}$} & \multirow{2}{*}{ Application target } & \multirow{2}{*}{$\begin{array}{l}\text { Recommended } \\
\text { dose }\end{array}$} & \multicolumn{5}{|c|}{$\begin{array}{c}\text { Concentration used in the } \\
\text { experiment }(\%)\end{array}$} \\
\hline & & & 1 & 2 & 3 & 4 & 5 \\
\hline $\begin{array}{l}\text { Effector, dithianon, } \\
700 \mathrm{~g} \mathrm{~kg}^{-1}\end{array}$ & $\begin{array}{l}\text { Apple fruit rot, } \\
\text { apple scab }\end{array}$ & $0.05-0.1 \%$ & 0.025 & 0.05 & 0.075 & 0.1 & 0.2 \\
\hline $\begin{array}{l}\text { Score } 250 \mathrm{EC} \text {, difenoconazole } \\
250 \mathrm{~g} \mathrm{l}^{-1}\end{array}$ & $\begin{array}{l}\text { Apple scab, } \\
\text { powdery mildew }\end{array}$ & $0.01-0.05 \%$ & 0.005 & 0.01 & 0.03 & 0.05 & 0.1 \\
\hline $\begin{array}{l}\text { Chorus } 50 \mathrm{WG} \text {, cyprodinil } \\
500 \mathrm{~g} \mathrm{~kg}^{-1}\end{array}$ & $\begin{array}{l}\text { Apple scab, fruit rot } \\
\text { of plums }\end{array}$ & $0.3-0.45 \mathrm{~kg} \mathrm{ha}^{-1}$ & 0.03 & 0.06 & 0.075 & 0.09 & 0.18 \\
\hline $\begin{array}{l}\text { Dithane NT, mancozeb } \\
750 \mathrm{~g} \mathrm{~kg}^{-1}\end{array}$ & Apple scab & $2.0 \mathrm{~kg} \mathrm{ha}^{-1}$ & 0.1 & 0.2 & 0.3 & 0.4 & 0.6 \\
\hline $\begin{array}{l}\text { Signum, boscalid } 26.7 \% \text {, } \\
\text { pyraclostrobin } 6.7 \%\end{array}$ & $\begin{array}{l}\text { Fruit rot of plum } \\
\text { and cherry }\end{array}$ & $0.75-1.0 \mathrm{~kg} \mathrm{ha}^{-1}$ & 0.075 & 0.15 & 0.17 & 0.2 & 0.4 \\
\hline
\end{tabular}

List of isolates used in the fungicide sensitivity tests

\begin{tabular}{|c|c|c|c|c|c|}
\hline Species & Orchard, cultivar & $\begin{array}{l}\text { Accession } \\
\text { number in } \\
\text { Genbank }\end{array}$ & Species & Orchard, cultivar & $\begin{array}{l}\text { Accession } \\
\text { number in } \\
\text { Genbank }\end{array}$ \\
\hline N. alba & $\begin{array}{l}\text { I, 'Beloruskoje } \\
\text { Malinovoje'* }\end{array}$ & Not submitted & N. malicorticis & $\begin{array}{l}\text { I, 'Beloruskoje } \\
\text { Malinovoje' }\end{array}$ & KP903612 \\
\hline N. alba & $\begin{array}{l}\text { I, 'Beloruskoje } \\
\text { Malinovoje' }\end{array}$ & КT923785 & N. alba & V, 'Antej’ & KP903587 \\
\hline N. malicorticis & I, ‘Sinap Orlovskij’ & KP903615 & N. malicorticis & VI, 'Forele' & KP903625 \\
\hline N. alba & I, 'Tellissaare'* & Not submitted & C. luteo-olivacea & III, ‘Sinap Orlovskij’ & KP903599 \\
\hline N. alba & II, 'Ligol' & КT923786 & C. luteo-olivacea & $\begin{array}{l}\text { IV, 'Beloruskoje } \\
\text { Malinovoje' }\end{array}$ & KP903596 \\
\hline N. alba & II, 'Lobo' & KP903582 & C. luteo-olivacea & VI, 'Forele' & KP903623 \\
\hline N. alba & II, 'Tellissaare' & КT923787 & A. alternata & II, 'Auksis' & KP903568 \\
\hline N. alba & $\begin{array}{l}\text { III, 'Sinap } \\
\text { Orlovskij' }\end{array}$ & КT923788 & A. alternata & II, 'Ligol' & KР903579 \\
\hline N. alba & $\begin{array}{l}\text { IV, 'Beloruskoje } \\
\text { Malinovoje' }\end{array}$ & КT923789 & A. alternata & II, 'Tellissaare' & KP903586 \\
\hline N. alba & VII, ‘Auksis' & KP903614 & A. alternata & II, 'Auksis' & KP903571 \\
\hline N. alba & VII, ‘Auksis’ & Not submitted & A. alternata & $\begin{array}{l}\text { VI, 'Beloruskoje } \\
\text { Malinovoje' }\end{array}$ & KР903621 \\
\hline N. malicorticis & I, 'Sinap Orlovskij' & KP903618 & A. alternata & III, 'Sinap Orlovskij & KР903601 \\
\hline N. malicorticis & I, 'Sinap Orlovskij' & KP903591 & - & - & - \\
\hline
\end{tabular}


using in vitro agar plate test (Russell, 2002). Two additional $N$. alba isolates originated from the orchard VII (Table 1). A complete list of isolates is given in Table 3. Each fungal isolate was grown in two replicates on PDA supplemented with particular fungicide in each concentration after autoclaving just before the test. Concentrations 1 and 5 were twice lower or twice higher than minimal and maximal doses recommended by a producer. Other concentrations were within the recommended range. The recommended dose for Dithane NT corresponded to the concentration 4 . The theoretical spraying volume used for calculations was $5001 \mathrm{ha}^{-1}$. Fungi were incubated at $25^{\circ} \mathrm{C}$ for three weeks; after that the diameter of fungal colony was measured.

\section{Statistical Analysis}

The statistical analysis was performed with data from the fungicide sensitivity tests comparing the average colony diameters of isolates at presence of various fungicides and in control plates, and within isolates from the same species and among various species. The F-test, t-test $(\alpha=0.05)$ and correlation analysis were done with Excel (Microsoft, USA). Both Pearson correlation coefficients $(r)$ and determination coefficients $\left(\mathrm{R}^{2}\right)$ were calculated to determine the correlation strength among fungicide doses and average growth results of every species.

\section{Results}

In February and March, the total percentage of rotten apples of various cultivars and in different storage sites ranged from 3.55 to $58.88 \%$ (Table 4 ). Both types of infections - primary and secondary, were observed,. From infected apples Neofabraea spp. ranged from 0.33 to $50.88 \%$ depending on the cultivar. The most severely affected cultivar was 'Forele'. Fusarium spp. caused rot ranged from 0 to $2.22 \%$, Penicillium spp. from 0.04 to $5.34 \%$, Colletotrichum spp. from 0.12 to $3.13 \%$, Botrytis spp. from 0 to $3.37 \%$, Monilinia spp. from 0 to $21.08 \%$ (the most affected cultivar was 'Lobo'). In

Table 4

Total percentage of rotten apples of various cultivars and in different storage sites and percentage of particular rot type

\begin{tabular}{|c|c|c|c|c|c|c|c|c|c|c|c|c|}
\hline Cultivar & $\begin{array}{c}- \\
0 \\
5 \\
0 \\
8 \\
8 \\
0 \\
0 \\
8 \\
8 \\
z\end{array}$ & 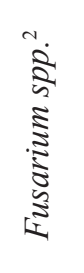 & 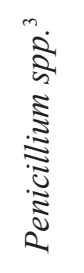 & 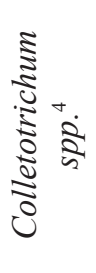 & 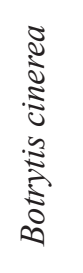 & 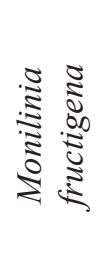 & 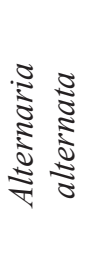 & 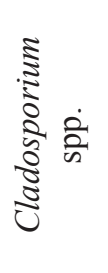 & 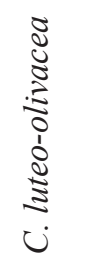 & $\begin{array}{l}\frac{2}{\mathbb{Q}} \\
\frac{\tilde{O}}{0}\end{array}$ & 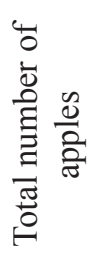 & 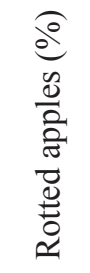 \\
\hline \multicolumn{13}{|l|}{ Storage in Bauska region } \\
\hline 'Tellissaare' & 0.33 & 0.15 & 0.37 & 0.33 & 3.37 & 0.18 & 0.04 & 0.18 & 0.00 & 0.00 & 2728 & 4.95 \\
\hline 'Auksis' & 3.29 & 2.22 & 5.34 & 1.51 & 0.27 & 0.00 & 0.31 & 0.00 & 0.00 & 0.00 & 2249 & 12.89 \\
\hline 'Lobo' & 0.90 & 0.30 & 0.60 & 0.15 & 0.00 & 21.08 & 0.00 & 0.30 & 0.00 & 0.00 & 664 & 23.34 \\
\hline 'Ligol' & 0.95 & 0.24 & 2.25 & 0.12 & 0.06 & 0.12 & 0.06 & 0.00 & 0.00 & 0.00 & 1690 & 3.55 \\
\hline \multicolumn{13}{|c|}{ Joint storage for several farmers in Pure region } \\
\hline 'Antej' & 3.80 & 0.00 & 0.29 & 1.58 & 0.06 & 0.29 & 0.06 & 0.00 & 0.06 & 0.00 & 1709 & 6.14 \\
\hline 'Beloruskoje Malinovoje’' & 6.38 & 0.00 & 0.51 & 2.42 & 0.05 & 0.10 & 0.00 & 0.00 & 0.00 & 0.41 & 1945 & 9.87 \\
\hline 'Sinap Orlovskij' & 4.24 & 0.19 & 0.64 & 2.44 & 0.51 & 0.51 & 0.06 & 0.26 & 0.06 & 0.32 & 1557 & 9.31 \\
\hline \multicolumn{13}{|l|}{ Storage in Vandzene region } \\
\hline 'Beloruskoje Malinovoje’ & 9.26 & 0.04 & 0.53 & 1.24 & 0.89 & 0.09 & 0.04 & 0.00 & 0.00 & 0.75 & 2258 & 12.84 \\
\hline 'Forele' & 50.88 & 0.25 & 1.00 & 3.13 & 2.88 & 0.50 & 0.00 & 0.13 & 0.13 & 0.00 & 800 & 58.88 \\
\hline \multicolumn{13}{|l|}{ Storage in Beverina region } \\
\hline 'Sinap Orlovskij' & 1.59 & 0.04 & 0.04 & 0.09 & 0.04 & 0.13 & 0.00 & 0.00 & 0.00 & 2.04 & 1562 & 5.76 \\
\hline 'Beloruskoje Malinovoje' & 8.00 & 0.13 & 0.13 & 0.00 & 1.00 & 1.13 & 0.38 & 0.00 & 0.00 & 4.38 & 1215 & 9.96 \\
\hline
\end{tabular}




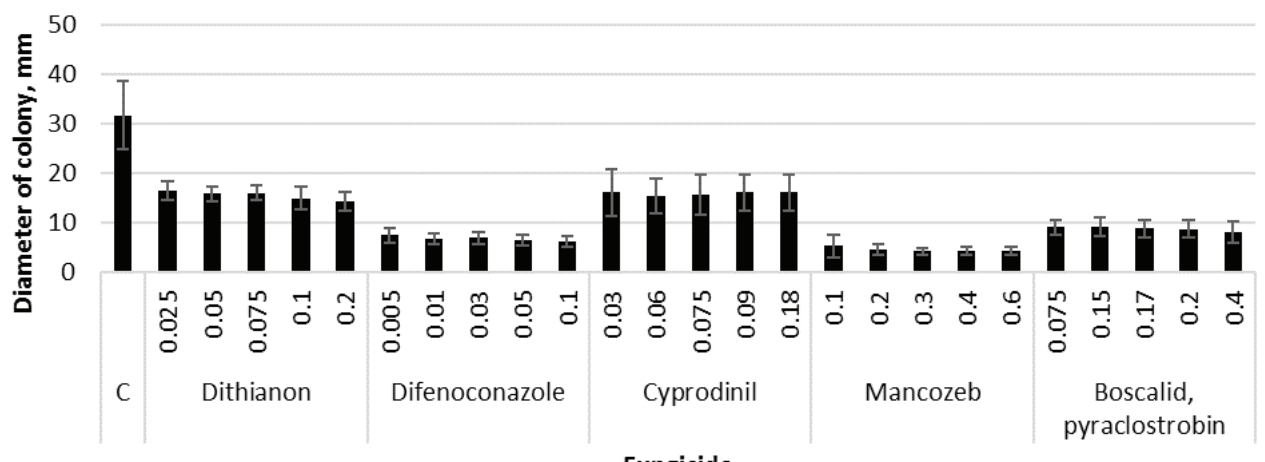

Figure 1. Sensitivity of $N$. alba isolates to five fungicides (C - control without fungicides).

Error bars indicate standard deviations $( \pm \mathrm{SD}), n=11$.

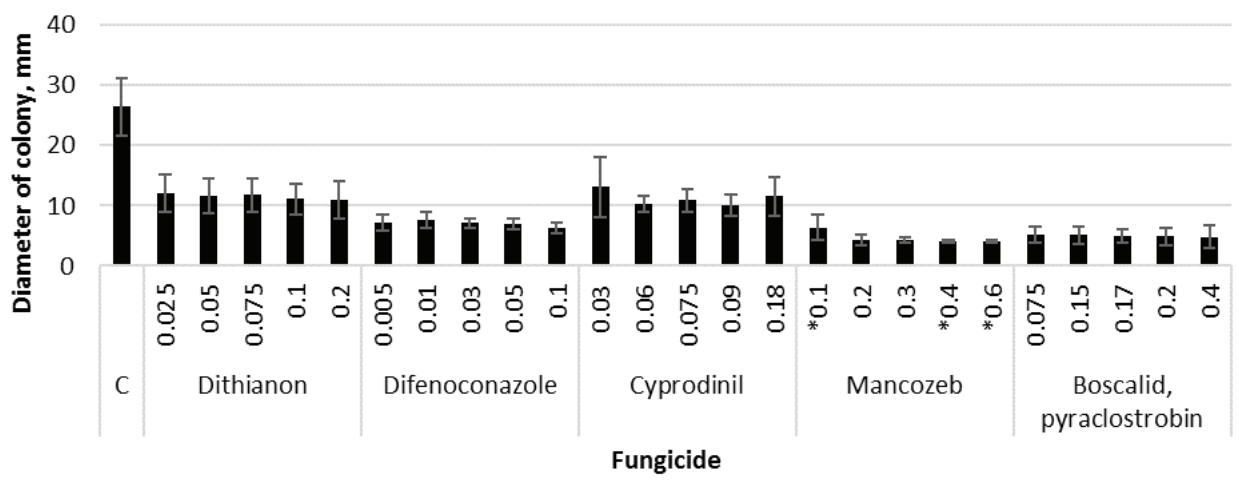

Figure 2. Sensitivity of $N$. malicorticis isolates to five fungicides (C-control without fungicides).

Statistically significant differences in dose response are indicated with an asterisk.

Error bars indicate standard deviations $( \pm \mathrm{SD}), n=5$.

two storehouses apple rot caused by C. luteo-olivacea was detected, and its identity was successfully proved by PCR with primers specific to this species (data not shown). A. alternata and Cladosporium spp. were detected on a few apples as secondary infection agents. None of the $A$. alternata isolates gave positive amplification products with primers specific to $A M T$ gene.

Application of Koch's postulates was successfully carried out with C. gloeosporioides, N. alba, F. avenaceum and Penicillium expansum on six apple varrieties: 'Auksis', 'Belorusskoje Malinovoje', 'Iedzēnu', 'Sinap Orlovskij', 'Tellissaare' and 'Saltanat', and with C. luteo-olivacea on 'Auksis' and 'Zarja Alatau'.

Results of fungicide sensitivity tests are shown in Figure 1 to 4 . Isolates of $N$. alba and $N$. malicorticis were sensitive to difenoconazole, mancozeb and boscalid with pyraclostrobin which reduced the growth of these fungi by $70-80 \%$. Dithianon and cyprodinil reduced the fungal growth only by $50 \%$ (Figures 1 and 2). In general, isolates of $N$. malicorticis were significantly slowly growing ( $p<$ 0.001 ), but the average response to fungicides was not significantly different.

Three isolates of $N$. alba from the orchards IV, V and VII were significantly less sensitive to the tested fungicides in comparison to the rest of isolates ( $p$ $<0.05$ ), especially to the dithianon and cyprodinil. The growth of these isolates in the presence of the dithianon was reduced only by 41,45 and $43 \%$, respectively, at the highest fungicide concentration. In the presence of the cyprodinil the growth was reduced only by 41,36 and $35 \%$, respectively, at the presence of the highest fungicide concentration.

From five isolates of $N$. malicorticis one isolate originating from the orchard I (KP903612) showed less sensitivity to dithianon in comparison to the rest of isolates. The growth of this isolate was reduced only by $51 v s .64 \%$ in the presence of the highest fungicide concentration.

Differences of dose response of $N$. alba isolates to tested fungicides were not statistically significant. In the case of $N$. malicorticis statistically significant 


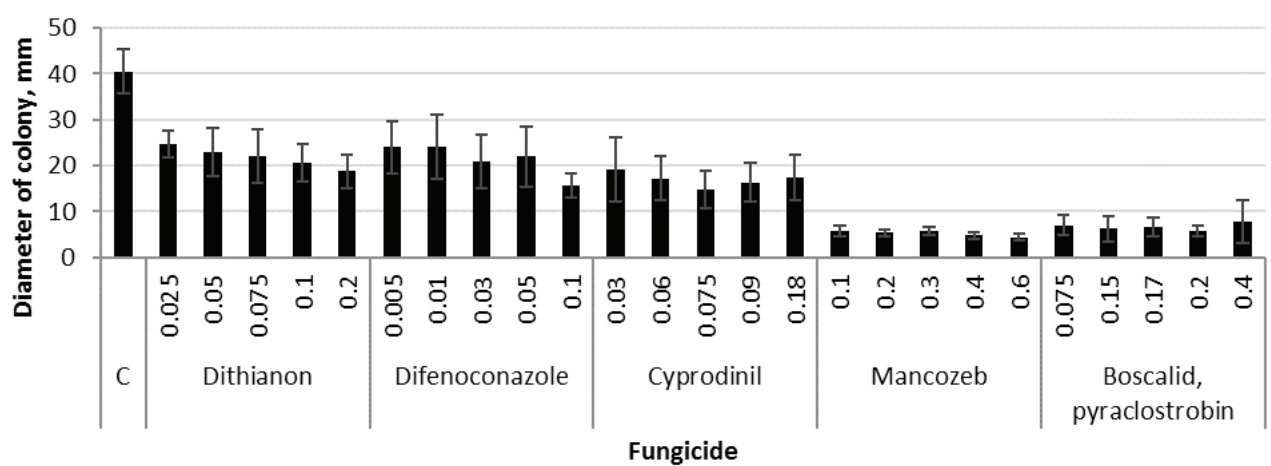

Figure 3. Sensitivity of C. luteo-olivacea isolates to five fungicides (C - control without fungicides).

Error bars indicate standard deviations $( \pm \mathrm{SD}), n=4$.

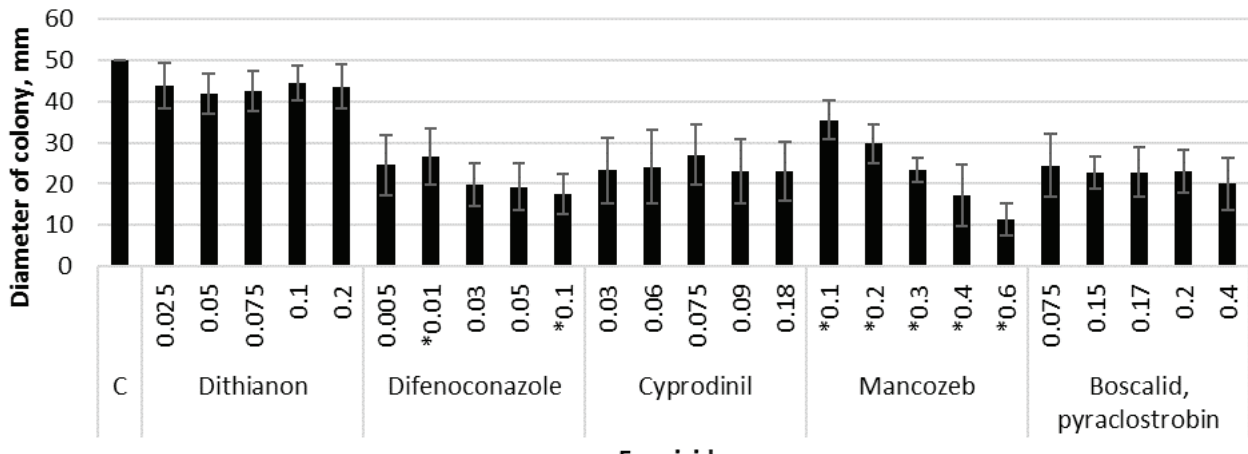

Fungicide

Figure 4. Sensitivity of $A$. alternata isolates to five fungicides ( $\mathrm{C}-$ control without fungicides).

Statistically significant differences in dose response are indicated with an asterisk.

Error bars indicate standard deviations $( \pm \mathrm{SD}), n=7$.

differences $(p<0.05)$ in the dose response were detected only in the case of mancozeb $\left(r=-0.70, \mathrm{R}^{2}\right.$ $=0.49$ ).

Isolates of C. luteo-olivacea were sensitive only to mancozeb and boscalid with pyraclostrobin, which reduced the growth of these fungi on average by $85 \%$. Other fungicides were less effective, reducing the growth of these fungi only by $50-60 \%$ (Figure 3). Differences of dose response of C. luteo-olivacea isolates against tested fungicides were not statistically significant although the correlation between dithianon and difenoconazole doses and average colony diameters was strong $\left(r=0.95, \mathrm{R}^{2}=0.92\right)$.

Isolates of $A$. alternata were medium sensitive to difenoconazole, cyprodinil, mancozeb and boscalid and pyraclostrobin, on average reducing the fungal growth by $50 \%$, the dithianon was the least effective reducing the growth only by $13 \%$ (Figure 4 ). One isolate from the orchard II was $100 \%$ resistant to all concentrations of the dithianon. On average, $A$. alternata isolates showed statistically significant differences in dose response against mancozeb $\left(r=-0.98, \mathrm{R}^{2}=0.97\right)$ and particularly against difenoconazole $\left(r=-0.85, \mathrm{R}^{2}=0.72\right)$.

\section{Discussion}

The species spectrum of apple rot-associated fungi identified in the present study was mainly identical to the causing agent spectrum described in the literature. The exception was the rubbery rot caused by $P$. washingtonensis that is considered as a new emerging disease in Northern Europe, and it is reported to cause rot in up to $10 \%$ of apples stored in ULO conditions (Weber, 2011), but it was not detected in the present investigation. The second exception was side rot caused by $C$. luteo-olivacea that is not so common in other studies, but it was detected in two storage sites in Latvia. This pathogen is reported as important kiwi pathogen especially during long storage periods, but it has also been found on apples (Spadaro et al., 2011).

From the apples in three storage sites several isolates of Phomopsis velata (imperfect stage of Diaporthe eres) were isolated. This fungus has been previously described as common pathogen of peach 
(Prunus persica (L.) Stokes) causing shoot blight and canker disease of peach in Greece (Thomidis \& Michailides, 2009) and minor disease of apple and pear in North America, Europe and Japan causing cankers and fruit decay (Sutton et al., 2014).

Several Penicillium species (P. brevicompactum, $P$. echinulatum, $P$. expansum, $P$. solitum. $P$. expansum and $P$. solitum) were isolated, which are common apple rot-causing pathogens (Sholberg et al., 2005). Isolates of $P$. brevicompactum have been isolated from rotten apples in Canada (Sholberg \& Haag, 1996). $P$. echinulatum have been found on lipid-rich substrates and wood residues (Frisvad \& Samson, 2004).

Aureobasidium pullulans was isolated from the cultivar 'Beloruskoje Malinovoje' (orchard I) only once and has been characterized as causing agent of miscellaneous postharvest diseases of apples (Sutton et al., 2014).

N. galligena was isolated from the cultivar 'Lobo' (orchard II) only once and is reported as rot -causing agent of apples (Maxin et al., 2012a, 2012b).

The proportion of rotten apples varied from 3.55 to $58.88 \%$ and was more cultivar-specific, not related to the number of fungicide treatments or storage conditions. For example, in the storage of orchard II four cultivars were examined having the same fungicide treatments and storage conditions, but the respective proportion of rotten apples varied from 3.55 ('Ligol') to $23.34 \%$ ('Lobo'). Differences of cultivars in infection level have been described in other investigations, for instance, in the case of infections with Fusarium spp. (Sever et al., 2012).

It is reported that $N$. alba shows low sensitivity to fungicides. For instance, in the study in Southern Oregon it was detected that in in vivo conditions only copper sulfate reduced the conidial production by $N$. alba but none of the fungicides used (copper sulfate, trifloxystrobin, ziram) reduced the germination of conidia (Henriquez, Sugar, \& Spotts, 2006). In the present investigation isolates of $N$. alba as well $N$. malicorticis showed high sensitivity to the tested fungicides: difenoconazole, mancozeb and boscalid with pyraclostrobin reduced the growth of these fungi by $70-80 \%$, dithianon and cyprodinil reduced the fungal growth by $50 \%$.

Three isolates of $N$. alba from the orchards IV, $\mathrm{V}$ and VII were less sensitive to tested fungicides, especially to dithianon and cyprodinil. The orchard VII had one of the highest numbers of fungicide treatments in 2013 (seven), but the orchards IV and $\mathrm{V}$ had an average number of treatments (Table 1). On the orchard VII the dithianon-containing fungicides were used twice and cyprodinil-containing fungicides were used three times in the growing season of 2013.
From five N. malicorticis isolates one isolate originating from the orchard I showed less sensitivity to dithianon and cyprodinil in comparison with the rest of the isolates. Orchard I had one of the highest numbers of fungicide treatments in 2013 (six). Orchard VI from which one isolate of $N$. malicorticis originated had smaller numbers of treatments four. In the orchard I the dithianon was not used but cyprodinil-containing fungicides were used twice. In orchard VI fungicides containing dithianon or cyprodinil were not used in 2013.

Sensitivity of $A$. alternata isolates to tested fungicides was medium high by comparison to other fungi and also to other investigations. For example, in the study in Lithuania, it was detected that the growth of $A$. alternata isolated from lovage and cabbage was reduced by $80 \%$ in the case of boscalid with pyraclostrobin (Signum) in comparison with 55\% in the present study (Surviliene \& Dambrauskiene, 2006). One isolate from the orchard II was $100 \%$ resistant to all concentrations of the dithianon. The dithianon in this orchard was applied three times during 2013 and up to five times in the previous two years.

In fungicide efficacy trials in Czech Republic, it was stated that strobilurines were the most effective fungicides against the storage rot of cultivar 'Golden Delicious' caused by $N$. alba, N. malicorticis and Penicillium spp. (Mináŕ, 2006). Slightly lower efficacy was shown by tolylfluanid, dodine and captan. Dithianon-containing fungicide was the least effective as it was observed in the present investigation. Since 2015 dodine is registered in Latvia against apple scab. Captan is registered against apple scab and fruit rot, but the strobilurin-containing fungicide Signum which is registered against fruit rot of plum and cherry can be used with special individual permissions on apple.

In the present investigation, the cyprodinilcontaining fungicide showed the lowest inhibition effect on tested fungal species. However, it has shown efficacy against postharvest apple rot caused by $B$. cinerea in Canada (Sholberg, Bedford, \& Stokes, 2003).

A few isolates with reduced sensitivity to tested fungicides found in the present study illustrate the tendency that larger numbers of fungicide applications are causing lesser sensitivity of pathogenic fungi against fungicides. Development of fungicide resistance of pathogens is one of the problems demanding for new control strategies (De Capdeville et al., 2002).

\section{Conclusions}

1. The most common apple fruit rot causing agents were Neofabraea alba, Neofabraea malicorticis, 
Fusarium spp., Penicillium spp., Colletotrichum spp., Botrytis cinerea, Monilinia fructigena. The following species Cadophora luteo-olivacea, Phomopsis velata and Alternaria alternata were considered of minor importance.

2. The most severely affected cultivar by Neofabraea spp. was 'Forele' but the most affected cultivar by Monilinia spp. was 'Lobo'. The least infected cultivars in general were 'Tellissaare' and 'Ligol'.

3. In general, the sensitivity of tested fungi to the fungicides was high with exception of particular Neofabraea and Alternaria isolates. The most effective fungicides were difenoconazole, mancozeb and pyraclostrobin-containing fungicides. Recent changes in the list of fungicides that are registered in Latvia on apples can help growers to diversify the fungicide spectrum including in the treatments dodine- and captan-containing fungicides which have shown good efficacy against storage diseases of apples in other countries.

4. The investigation should be continued increasing the number of orchards, storehouses and cultivars.

\section{References}

1. Bonfield, J.K., Smith, K.F. and Staden, R. (1995). A new DNA sequence assembly program. Nucleic Acids Research 23 (24): 4992-4999. DOI: $10.1093 / \mathrm{nar} / 23.24 .4992$.

2. Borve, J., Roen, D., Stensvand, A. (2013). Harvest time influences incidence of storage diseases and fruit quality in organically grown 'Aroma' apples. European Journal of Horticultural Science 78 (5): 232-238.

3. Crous, P.W., Verkley, G.J.M., Groenewald, J.Z., Samson, R.A. (2009). Fungal biodiversity. Utrecht, The Netherlands: CBS-KNAW Fungal Biodiversity Centre.

4. De Capdeville, G., Wilson, C. L., Beer, S. V., Aist, J. R. (2002). Alternative disease control agents induce resistance to blue mold in harvested 'Red Delicious' apple fruit. Phytopathology 92 (8): 900-908. Retrieved date of access May 15, 2015, from http://dx.doi.org/10.1094/ PHYTO.2002.92.8.900.

5. DeEll, J.R., Prange, R.K. (1993). Postharvest physiological disorders, diseases and mineral concentrations of organically and conventionally grown Mclntosh and Cortland apples. Canadian Journal of Plant Science 73 (1): 223-330. DOI: 10.4141/cjps93-036.

6. Dutot, M., Nelson, L.M., Tyson, R.C. (2013). Predicting the spread of postharvest disease in stored fruit, with application to apples. Postharvest Biology and Technology 85 (1): 45-56. DOI:10.1016/j.postharvbio.2013.04.003.

7. Gardes, M., Bruns, T.D. (1993). ITS primers with enhanced specificity for basidiomycetes application to the identification of mycorrhizae and rusts. Molecular Ecology 2 (2): 113-118. DOI: 10.1111/j.1365-294X.1993.tb00005.x.

8. Henriquez, J.L., Sugar, D., Spotts, R.A. (2006). Induction of cankers on pear tree branches by Neofabraea alba and $N$. perennans, and fungicide effects on conidial production on cankers. Plant Disease 90 (4): 481-486. DOI:10.1094/PD-900481

9. Holb, I.J. (2008). Monitoring conidial density of Monilinia fructigena in the air in relation to brown rot development in integrated and organic apple orchards. European Journal of Plant Pathology 120 (4): 397-408. DOI:10.1094/ PHYTO-98-1-0079.

10. Frisvad, J.C., Samson, R.A. (2004). Polyphasic taxonomy of Penicillium subgenus Penicillium. A guide to identification of food and air-borne terverticillate Penicillia and their mycotoxins. Studies in Mycology 49 (1): 1-174.

11. Johnson, R.D., Johnson, L., Kohmoto, K., Otani, H., Lane, C.R., Kodama, M. (2000). A polymerase chain reaction-based method to specifically detect Alternaria alternata apple pathotype ( $A$. mali), the causal agent of Alternaria blotch of apple. Phytopathology 90 (9): 973-976. DOI: 10.1094/PHYTO.2000.90.9.973.

12. Mari, M., Guidarelli, M., Martini, C., Spadoni, A. (2012). First report of Colletotrichum acutatum causing bitter rot on apple in Italy. Plant Disease 96 (1): 144. DOI: 10.1094/PDIS-06-11-0483.

13. Maxin, P., Weber, R.W.S., Pedersen, H.L., Williams, M. (2012a). Control of a wide range of storage rots in naturally infected apples by hotwater dipping and rinsing. Postharvest Biology and Technology 70 (1): 25-31. DOI: 10.1016/j. postharvbio.2012.04.001.

14. Maxin, P., Weber, R.W.S., Pedersen, H.L., Williams, M. (2012b). Hot-water dipping of apples to control Penicillium expansum, Neonectria galligena and Botrytis cinerea: effects of temperature on spore germination and fruit rots. European Journal of Horticultural Science 77 (1):1-9.

15. Minár, P. (2006). Effect of late summer treatments by strobilurines on storage diseases of apples. Acta Universitatis Agriculturae et Silviculturae Mendelianae Brunensis, 54 (4): 39-44. Retrieved date of access May 15, 2015, from http://dx.doi. org/10.11118/actaun200654040039. 
16. Morales, H., Marin, S., Ramos, A.J., Sanchis, V. (2010). Influence of post-harvest technologies applied during cold storage of apples in Penicillium expansum growth and patulin accumulation: A review. Food Control 21 (7): 953-962. DOI: 10.1016/j.foodcont.2009.12.016.

17. Niem, J., Miyara, I., Ettedgui, Y., Reuveni, M., Flaishman, M., Prusky, D. (2007). Core rot development in red delicious apples is affected by susceptibility of the seed locule to Alternaria alternata colonization. Phytopathology 97 (11): 1415-1421. DOI: 10.1094/PHYTO-97-11-1415.

18. Reuveni, M., Sheglov, D. (2002). Effects of azoxystrobin, difenoconazole, polyoxin B (polar) and trifloxystrobin on germination and growth of Alternaria alternata and decay in red delicious apple fruit. Crop Protection 21 (10): 951-955. PII: S0261-2194 (02) 00073 - X.

19. Russell, P.E. (2002). Sensitivity baselines in fungicide resistance research and management. FRAC Monograph No. 3. Brussels, Belgium: Crop Life International.

20. Sever, Z., Ivić, D., Kos, T., Miličević, T. (2012). Identification of Fusarium species isolated from stored apple fruit in Croatia. Archives of Industrial Hygiene and Toxicology 63 (4): 463470. DOI: $10.2478 / 10004-1254-63-2012-2227$.

21. Sholberg, P.L., Bedford, K.E., Stokes, S. (2003). Effect of preharvest application of cyprodinil on postharvest decay of apples caused by Botrytis cinerea. Plant Disease 87(9): 1067-1071. Retrieved date of access May 15, 2015, from http://dx.doi.org/10.1094/PDIS.2003.87.9.1067.

22. Sholberg, P.L., Harlton, C., Haaga, P., L'evesque, C.A., O'Gormana, D., Seifert, K. (2005). Benzimidazole and diphenylamine sensitivity and identity of Penicillium spp. that cause postharvest blue mold of apples using $\beta$-tubulin gene sequences. Postharvest Biology and Technology 36 (1): 41-49. DOI: 10.1016/j. postharvbio.2004.07.011.

23. Sholberg, P.L., Haag, P.D. (1996). Incidence of postharvest pathogens of stored apples in British Columbia. Canadian Journal of Plant Pathology 18 (1): 81-85. DOI: 10.1080/07060669609500661.

24. Spadaro, D., Pellegrino, C., Garibaldi, A., Gullino, M.L. (2011). Development of SCAR primers for the detection of Cadophora luteo-olivacea on kiwifruit and pome fruit and of Cadophora malorum on pome fruit. Phytopathologia Mediterranea 50 (3): 430-441. DOI:10.14601/Phytopathol_Mediterr-9457.

25. Surviliene, E., Dambrauskiene, E. (2006). Effect of different active ingredients of fungicides on Alternaria spp. growth in vitro. Agronomy Research 4 (Special issue): 403-406.

26. Sutton, T.B., Aldwinckle, H.S., Agnello, A.M., Walgenbach, J.F. (2014). Compendium of Apple and Pear Diseases and Pests. APS Press.

27. Thomidis, T., Michailides, T.J. (2009). Studies on Diaporthe eres as a new pathogen of peach trees in Greece. Plant Disease 93 (12): 12931297. DOI: 10.1094/PDIS-93-12-1293.

28. Xiao, C.L., Boal, R.J. (2009). Preharvest application of a boscalid and pyraclostrobin mixture to control postharvest gray mold and blue mold in apples. Plant Disease 93 (2):185189. DOI: 10.1094/PDIS-93-2-0185.

29. Xiao, C.L., Rogers, J.D. (2004). A postharvest fruit rot in d'Anjou pears caused by Sphaeropsis pyriputrescens sp. nov. Plant Disease 88 (2):114118. Retrieved date of access May 15,2015, from http://dx.doi.org/10.1094/PDIS.2004.88.2.114.

30. Volkova, J., \& Juhnevica-Radenkova, K. (2015). Ābolu rūgtā puve - dažādi ierosinātāji, divas dažādas slimības (Bitter rot of apple: different causal agents, two diseases). In Scientific and Practical Conference "Harmonius Agriculture", 19-20 February 2015 (pp. 149-152). Jelgava, Latvia: Latvia University of Agriculture. (in Latvian).

31. Watanabe, T. (2002). Pictorial atlas of soil and seed fungi: morphologies of cultured fungi and key to species. ( $2^{\text {nd }}$ ed.). Boca Raton: CRC Press.

32. White, T.J., Bruns, T., Lee, S., Taylor, J. (1990). Amplification and direct sequencing of fungal ribosomal RNA genes for phylogenetics. In Innis, M.A., Gelfand, D.H., Sninsky, J.J., White, T.J. (Eds.), PCR protocols. A guide to methods and applications (315-322). USA: Academic Press, Inc.

33. Weber, R.W.S. (2011). Phacidiopycnis washingtonensis, cause of a new storage rot of apples in Northern Europe. Journal of Phytopathology 159 (10): 682-686. DOI: 10.1111/j.1439-0434.2011.01826.x

\section{Acknowledgements}

The present study was supported by the European Agricultural Fund for Rural Development funded project "Sustainable development of fruit growing, using environment-friendly and water saving, as well as the rural landscape retaining integrated production technologies to reduce climate changes and to maintain biodiversity" No. 080410/c-32. 